\title{
特発性および骨折後肩関節拘縮に対する 鏡視下授動術の治療成績
}

\author{
高 橋 宗 志* 佐々木 宏 介* 藤 井 陽 生*
}

\begin{abstract}
特発性肩関節拘縮 12 例 12 肩（I 群）および骨折後拘縮 6 例 6 肩（F 群）を対象とし，鏡視下授動術の 治療成績を検討した。平均手術時年齢は I 群 61.2 歳/F 群 63.7 歳, 平均術後調査期間は I 群 15.2 力月/F 群 16.3 力月であつた。術前と最終調査時において，肩関節の JOA score および可動域（挙上/外旋/内 旋）を調査し比較した。術前の平均 JOA score/挙上/外旋/内旋は, I 群が $52.7 / 82^{\circ} / 12^{\circ} /$ 仙骨, F 群 が $55.3 / 85^{\circ} / 9^{\circ} /$ 仙骨であつた。最終調査時の平均 JOA score/挙上/外旋/内旋は, I 群が $91.0 / 142^{\circ} / 43^{\circ}$

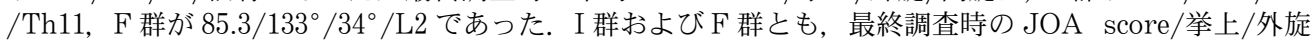
/内旋は，全て術前より有意に改善していた（P<0.05）。鏡視下授動術は，特発性および骨折後拘縮に対 する有効な治療法と考えられた.
\end{abstract}

Key words : shoulder stiffness (肩関節拘縮), arthroscopic capsular release（鏡視下授動術), idiopathic (特発性), post-fracture（骨折後）

は じめに

肩関節拘縮は, 原因不明の一次性（特発性）拘縮と 原因を有する二次性拘縮に分類される ${ }^{4}$. 特発性拘縮 とはいわゆる凍結肩（五十肩）であり，二次性拘縮と は外傷・手術・腱板断裂・石灰沈着性腱板炎などに続 発して生じる拘縮である ${ }^{4}$. 肩関節拘縮に対しては, 一次性および二次性拘縮とも, 投薬・関節注射・リハ ビリ・joint distensionなどの保存治療が原則として まず行われる4). しかし，これらの保存治療に抵抗性 の難治例に対しては，麻酔下での非観血的授動術や鏡 視下授動術が施行されている ${ }^{4)}$. 今回我々は, 特発性 および骨折後肩関節拘縮に対する鏡視下授動術の治療 成績を検討したので報告する.

\section{対象と方法}

対象は，当科で鏡視下授動術を行った特発性肩関節 拘縮 12 例 12 肩（I 群）と骨折後拘縮 6 例 6 肩（F 群） である. I 群は, 男性 5 例/女性 7 例, 平均手術時年齢 $61.2 （ 44 \sim 74 ）$ 歳, 平均術後調査期間 $15.2 （ 6 ３ 6 ）$ 力 月であった. F 群は, 男性 3 例/女性 3 例, 平均手術 時年齢 $63.7(48 \sim 79)$ 歳, 平均術後調查期間 16.3（6 〜36） カ月であった． F 群の内訳は，上腕骨近位端骨
折後 5 肩/鎖骨遠位端骨折後 1 肩（骨接合術後 3 肩/ 保存治療後 3 肩）であった。 また上腕骨近位端骨折 5 肩の内, 4 肩が大結節単独骨折, 1 肩が 3-part 骨折で あった. 手術適応は原則として, 3 カ月以上の保存治 療に抵抗して高度な可動域制限（挙上 $90^{\circ}$ 以下または 外旋 20 以下）が持続する症例とした. しかしこの基 準を満たさなくとも，生活事情から患者さんが早期の 肩関節機能改善を希望された場合は手術適応とした. また術前の肩関節造影検査で，肩甲上腕 $(\mathrm{GH})$ 関節 腔の明らかな狭小化を認めない場合には，手術適応外 とした.

手術は全例, 全身麻酔下でビーチチェアーポジショ ンにて行った. 前方・前外側・後外側・後方の 4 力所 にポータルを作製し, 腱板疎部の郭清・癒着解離, 全 周性（前方・上方・後方・下方）の関節包解離，肩峰 下腔の癒着解離を行い, 必要に応じて肩峰形成や大結 節形成による肩峰下除圧も追加した。 下方関節包解離 においては, 腋窩神経損傷の合併を避けるため, 必要 に応じて後下方ポータルを追加で作製し，鏡視と処置 を行った ${ }^{5) 8}$. 術後は疼痛の程度に応じて, 術翌日より 自動および他動での肩関節可動域訓練を行った. また, 全抜糸までは三角巾固定とした.

術前と最終経過観察時において, 日本整形外科学会

\footnotetext{
* JR 九州病院整形外科
} 
肩関節疾患治療成績判定基準（JOA score）と肩関節 可動域（挙上・外旋・内旋）を調査した. I 群および F 群内において, 術前と最終調査時の JOA score・挙 上・外旋・内旋を比較した。 また術前および最終調査 時において, I 群と F 群間でこれらを比較した。統計 学的比較検定は Wilcoxon signed-rank test, MannWhitney U test, paired t-test, unpaired t-test て行い, $\mathrm{P}<0.05$ の場合に統計学的有意差ありとした.

\section{結 果}

I 群の JOA score/挙上/外旋/内旋は, 術前が平均 $52.7(42 \sim 62) / 82(45 \sim 100) \circ / 12(-5 \sim 30)^{\circ} /$ 仙骨 (Th12〜臀部以下), 最終調査時は平均 91.0 (82〜 100) /142（125〜 160) \%/43（15〜 70) / Th11（Th7〜 L4）であり，最終調査時には全て術前より有意に改 善していた $(\mathrm{P}=0.002 / \mathrm{P}<0.001 / \mathrm{P}<0.001 / \mathrm{P}=0.002)$ (表 1). F 群の JOA score/挙上/外旋/内旋は, 術前
が平均 $55.3(45 \sim 62) / 85(60 \sim 100)^{\circ} / 9(0 \sim 20)^{\circ} /$ 仙 骨 (L2〜臀部以下), 最終調査時は平均 85.3（72～ 93) $/ 133(115 \sim 155)^{\circ} / 34(20 \sim 60)^{\circ} / \mathrm{L} 2 （$ Th11 L4) であり，I群と同様に最終調査時には全て術前より有 意に改善していた $(\mathrm{P}=0.027 / \mathrm{P}=0.002 / \mathrm{P}=0.002 / \mathrm{P}$ =0.027）（表 2）.また, 術前の JOA score/挙上/外 旋/内旋は I 群と $\mathrm{F}$ 群間で全て有意差を認めず $(\mathrm{P}=$ $0.424 / \mathrm{P}=0.714 / \mathrm{P}=0.585 / \mathrm{P}=0.726 ） （$ 表 $3 ） ，$ 最終調 査時にも全て有意差は認めなかった $(\mathrm{P}=0.303 / \mathrm{P}=$ $0.214 / \mathrm{P}=0.322 / \mathrm{P}=0.066 ） （$ 表 4$)$.

症例

【症例 1】55 歳・女性，右特発性肩関節拘縮に対し て 6 力月の保存治療を行つたものの, 右肩の疼痛と可 動域制限が強く，また日常生活動作（ADL）制限も 高度であったため，鏡視下授動術を施行した，術前の 右肩単純 X 線では，明らかな異常所見を認めなかつ

表 1 I 群の調査結果, 術前と最終調査時の比較

\begin{tabular}{|c|c|c|c|}
\hline & 術前 & 最終調査時 & $\mathrm{P}$ \\
\hline JOA score & $52.7(42 \sim 62)$ & $91.0(82 \sim 100)$ & 0.002 \\
\hline 挙上 & $82(45 \sim 100)^{\circ}$ & $142(125 \sim 160)^{\circ}$ & $<0.001$ \\
\hline 外旋 & $12(-5 \sim 30)^{\circ}$ & $43(15 \sim 70)^{\circ}$ & $<0.001$ \\
\hline 内旋 & 仙骨（Th12～殿部） & Th11 $($ Th7 L4) & 0.002 \\
\hline
\end{tabular}

表 $2 \mathrm{~F}$ 群の調査結果, 術前と最終調査時の比較

\begin{tabular}{lccc}
\hline \hline & 術前 & 最終調查時 & $\mathrm{P}$ \\
\hline JOA score & $55.3(45 \sim 62)$ & $85.3(72 \sim 93)$ & 0.027 \\
挙上 & $85(60 \sim 100)^{\circ}$ & $133(115 \sim 155)^{\circ}$ & 0.002 \\
外旋 & $9(0 \sim 20)^{\circ}$ & $34(20 \sim 60)^{\circ}$ & 0.002 \\
内旋 & 仙骨 $(\mathrm{L} 2 \sim$ 臀部 $)$ & L2 $($ Th11 L4) & 0.027 \\
\hline
\end{tabular}

$\mathrm{P}:$ Wilcoxon signed-rank test or paired t-test

表 3 術前の調査結果, I 群と $\mathrm{F}$ 群間での比較

\begin{tabular}{lccc}
\hline \hline & $\mathrm{I}$ 群 & $\mathrm{F}$ 群 & $\mathrm{P}$ \\
\hline JOA score & $52.7(42 \sim 62)$ & $55.3(45 \sim 62)$ & 0.424 \\
挙上 & $82(45 \sim 100)^{\circ}$ & $85(60 \sim 100)^{\circ}$ & 0.714 \\
外旋 & $12(-5 \sim 30)^{\circ}$ & $9(0 \sim 20)^{\circ}$ & 0.585 \\
内旋 & 仙骨 $(\mathrm{L} 2 \sim$ 慰部 $)$ & 仙骨 $(\mathrm{L} 2 \sim$ 臀部 $)$ & 0.726 \\
\hline \multicolumn{4}{r}{} \\
\hline \multicolumn{4}{c}{$\mathrm{P}:$ Mann-Whitney $\mathrm{U}$ test or unpaired t-test }
\end{tabular}


表 4 最終調査時の調査結果, I 群と F 群間での比較

\begin{tabular}{lccc}
\hline \hline & $\mathrm{I}$ 群 & $\mathrm{F}$ 群 & $\mathrm{P}$ \\
\hline JOA score & $91.0(82 \sim 100)$ & $85.3(72 \sim 93)$ & 0.303 \\
挙上 & $142(125 \sim 160)^{\circ}$ & $133(115 \sim 155)^{\circ}$ & 0.214 \\
外旋 & $43(15 \sim 70)^{\circ}$ & $34(20 \sim 60)^{\circ}$ & 0.322 \\
内旋 & $\mathrm{Th} 11(\mathrm{Th} 7 \sim \mathrm{L} 4)$ & $\mathrm{L} 2(\mathrm{Th} 11 \sim \mathrm{L} 4)$ & 0.066 \\
\hline \multicolumn{4}{c}{$\mathrm{P}:$ Mann-Whitney U test or unpaired t-test }
\end{tabular}

$\mathrm{P}$ : Mann-Whitney $\mathrm{U}$ test or unpaired t-test

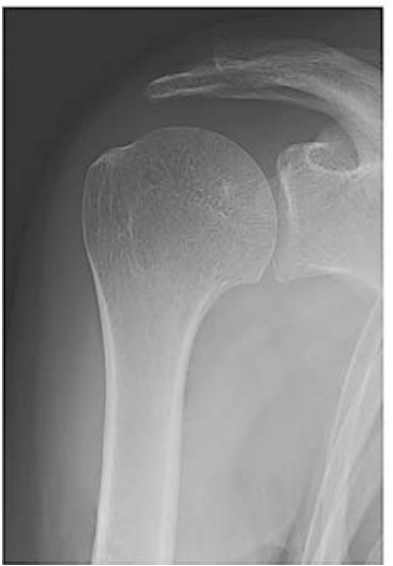

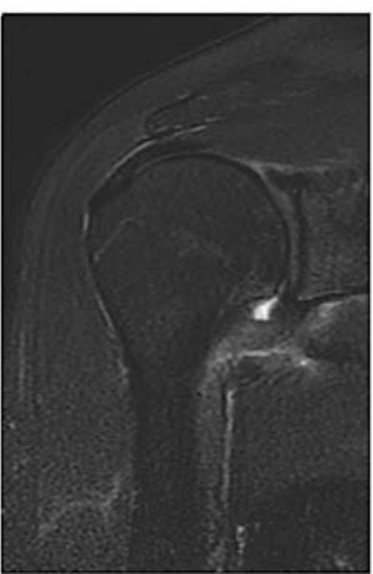

b

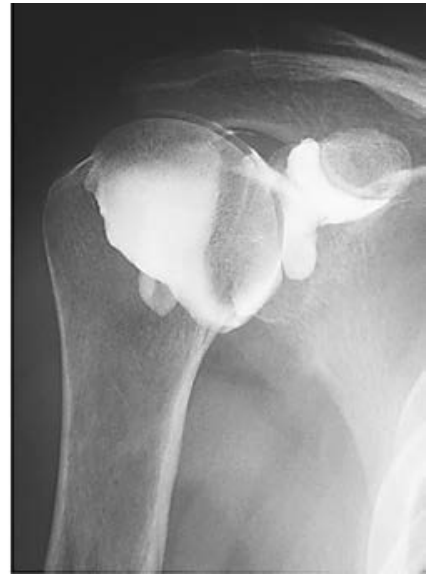

c

図 155 歳, 女性. 右特発性肩関節拘縮症例.

$\mathrm{a}$ ：術前の右肩単純 X 線正面像.

明らかな異常所見は認めない.

$\mathrm{b}$ : 術前の右肩 MRI 脂肪抑制 T2 強調斜位冠状断像.

下方関節包の肥厚, また axillary pouch の狭小化を認める.

c : 術前の右肩関節造影画像.

Axillary pouch の癒着と GH 関節腔狭小化を認める.

た（図 $1 \mathrm{a}$ ). 術前の右肩 MRI では, 下方関節包の肥 厚，また axillary pouch の狭小化を認めた（図 $1 \mathrm{~b}$ ). 術前の右肩関節造影検査では, axillary pouchの癒 着と $\mathrm{GH}$ 関節腔狭小化を認めた (図 $1 \mathrm{c}$ ). 術前の JOA score/挙上/外旋/内旋は, $47 / 70^{\circ} / 10^{\circ} /$ 仙骨で あった. 術後 1 年の最終調査時, JOA score/挙上/ 外旋/内旋は $95 / 155^{\circ} / 60^{\circ} / \mathrm{Th} 10$ となっており, 疼痛・ 可動域・ADL とも術前より著明に改善していた.

【症例 2】72 歳 - 女性, 左上腕骨近位端 3-part 骨折 に対する骨接合（anatomical locking plateを用い て人工骨移植併用) 術後 9 力月, 保存治療抵抗性の左 肩関節拘縮が残存し，また ADL 制限も高度であつた ため, 鏡視下授動術を行った. 術前の左肩単純 $\mathrm{X}$ 線
では，骨折部は良好なアライメントで骨癒合していた (図 $2 \mathrm{a}$ )。術前の左肩 MRI では, 明らかな腱板断裂 や上腕骨頭壊死は認めなかった（図 2 b). 術前の左 肩関節造影検査では, axillary pouchの癒着と $\mathrm{GH}$ 関節腔狭小化を認めた (図 $2 \mathrm{c}$ )。術前の JOA score/ 挙上/外旋/内旋は, $55 / 75^{\circ} / 10^{\circ} /$ 仙骨であった. 術後 1 年の最終調査時, JOA score/挙上/外旋/内旋は $72 / 115^{\circ} / 20^{\circ} / \mathrm{L} 2$ となっており, 疼痛・可動域・ADL とも術前より改善していたものの, 本研究の中で最終 調査時 JOA scoreが最も低い症例であった.

$$
\text { 考察 }
$$

本研究においては, 特発性および骨折後肩関節拘縮 


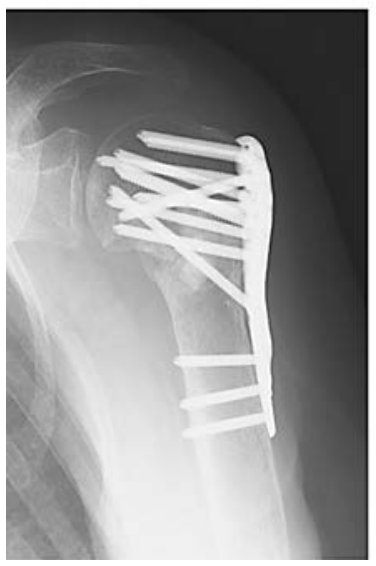

a

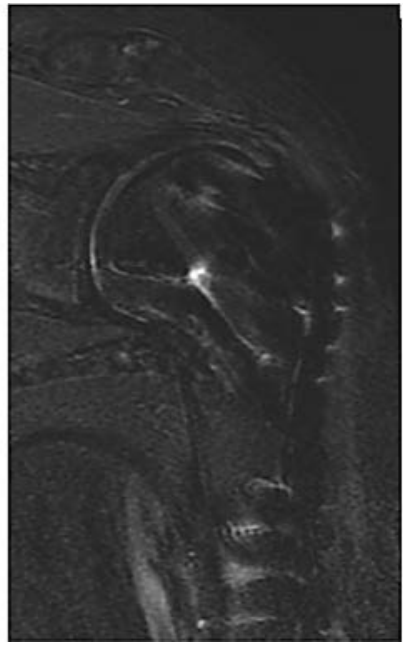

b

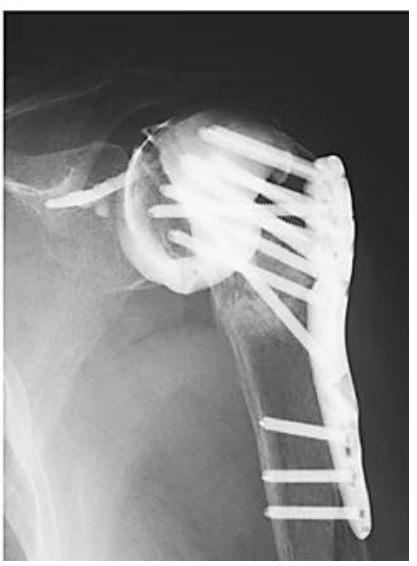

c

図 272 歳, 女性. 左上腕骨近位端骨折術後肩関節拘縮症例.

$\mathrm{a}$ : 術前の左肩単純 X 線正面像.

骨折部は良好なアライメントで骨癒合している。

$\mathrm{b}$ : 術前の左肩 MRI 脂肪抑制 T2 強調斜位冠状断像.

明らかな腱板断裂や上腕骨頭壊死は認めない.

c : 術前の左肩関節造影画像.

Axillary pouch の癒着と GH 関節腔狭小化を認める.

とも, 最終調查時の JOA score・肩関節可動域が術 前より有意に改善しており，鏡視下授動術は特発性お よび骨折後拘縮に対する有効な治療法と考えられた. 特発性拘縮に対する鏡視下授動術は，その良好な術後 長期成績も報告されており，コンセンサスが得られ広 く認知された治療法となっている ${ }^{14) 7}$. 一一方, 骨折後 拘縮に対する鏡視下授動術は，その治療成績に関する 報告が少ないため ${ }^{336)}$ ，コンセンサスの得られた治療法 とは言い難い ${ }^{2)}$. Holloway $ら^{3)}$ や菊川ら ${ }^{6)}$ の報告をま とめると, 骨折後拘縮の術後成績は特発性と同様に術 前より有意に改善しているが, 術後の疼痛・肩関節機 能・可動域・患者満足度などの内, 骨折後拘縮では特 発性より有意に劣る部分があると結論される。本研究 においては, 最終調査時の JOA score・可動域が特 発性と骨折後拘縮間で有意差を認めなかったが，これ は症例数が少なかつたためとも考えられる. 今後症例 数が増加すれば，再調査し再検討する必要があると 我々は考えている.

特発性肩関節拘縮の原因は，腱板疎部の癒着，関節
包の肥厚・短縮，肩峰下滑液包の癒着である ${ }^{4) 58)}$ 。一 方骨折後拘縮では，これらの要因に加えて，関節外軟 部組織の癒着や柔軟性の低下，また変形骨癒合による 骨摺動面の異常も原因として加わる ${ }^{2}$. 骨折後拘縮の 症例 2 は, 本研究の中で最終調査時 JOA score が最 も低い症例であった。術前, 明らかな変形骨癒合は認 めず，また上腕骨頭壊死や腱板断裂も認めず，一方肩 関節造影検査で明らかな $\mathrm{GH}$ 関節腔狭小化を認めた ため, 我々は鏡視下授動術の適応と判断した. しかし, 初回骨接合術により三角筋など関節外軟部組織へ侵襲 が加わつており，さらに受傷後や骨接合術後に一定の 肩関節不動期間があったこともあり，関節外軟部組織 の癒着と柔軟性低下が予想以上に大きく拘縮に関与し ていたため, 鏡視下授動術後に満足な治療成績が得ら れなかったと推察される. 以上のことを踏まえると, 骨折後拘縮に対する鏡視下授動術では，安定して良好 な術後成績が得られるとは言い難く, 術前に十分なイ ンフォームドコンセントを行い，また手術適応か否か を慎重に判断する必要があると思われる. 


\section{ま と め}

本研究結果より，鏡視下授動術は，特発性および骨 折後肩関節拘縮に対する有効な治療法と考えられた. しかし，本研究や過去の報告より，骨折後拘縮に対す る鏡視下授動術においては，特発性拘縮に対する場合 と異なり安定して良好な術後成績が得られるとは言い 難く, 手術適応か否かを慎重に判断する必要があると 思われる。

\section{参 考 文 献}

1) Harryman, D. T. 2nd., Matsen, F. A. 3rd., Sidles, J. A.: Arthroscopic management of refractory shoulder stiffness. Arthroscopy., $13: 133-147,1997$.

2）林田賢治：術後ならびに外傷後の関節拘縮. MB Orthop., $27: 67-69,2014$.
3) Holloway, G. B., et al.: Arthroscopic capsular release for the treatment of refractory postoperative or post-fracture shoulder stiffness. J. Bone Joint Surg. Am., 83 : 1682-1687, 2001.

4) Itoi, E., et al.: Shoulder stiffness: current concepts and concerns. Arthroscopy., 32 : 1402-1414, 2016.

5）岩堀裕介：難治性凍結肩に対する鏡視下関節授動術. 関節外科, $35: 1066-1071,2016$.

6）菊川和彦，奥平信義：肩関節周囲骨折後に生じた関節 拘縮に対する鏡視下授動術．肩関節，38：1008-1011, 2014.

7) Le Lievre, H. M., Murrell, G. A.: Long-term outcomes after arthroscopic capsular release for idiopathic adhesive capsulitis. J. Bone Joint Surg. Am., 94 : 1208-1216, 2012.

8）柴田陽三 : 凍結肩に対する鏡視下肩関節授動術（下方 関節包切離派)。関節外科, $36: 1090-1097,2017$. 